\title{
Metode Pembelajaran Melalui Film Superbook dan Minat Belajar Firman Tuhan Pada Anak Usia 6-8 Tahun
}

\section{The Method of Learning through the Film Superbook and Learning Interest God's Word to Child Age 6-8 years}

\author{
Yurika V. Bayoe, ${ }^{1 *}$ Meily L. Kouwagam, ${ }^{2)}$ Parel Tanyit ${ }^{3)}$ \\ 1) Prodi Pendidikan Agama Kristen, Sekolah Tinggi Filsafat Jaffray Makassar, Indonesia \\ 2) Prodi Pendidikan Agama Kristen, Sekolah Tinggi Filsafat Jaffray Makassar, Indonesia \\ 3) Prodi Pendidikan Agama Kristen, Sekolah Tinggi Filsafat Jaffray Makassar, Indonesia \\ *) Penulis korespondensi: vitriyurikal8@gmail.com
}

Received: 10 January 2019/Revised: 30 March 2019 /Accepted: 10 April 2019

\begin{abstract}
Abstrak
Tujuan penulisan ini ialah untuk mengkaji metode pembelajaran melalui film Superbook dan minat belajar firman Tuhan pada anak usia 6-8 tahun. Metode yang dipakai ialah metode penelitian kualitatif deskriptif dengan menggunakan studi kepustakaan dan penelitian lapangan berupa observasi dan wawancara kepada anak usia 6-8 tahun. Kriteria anak yang berminat jika anak senang untuk belajar, tertarik untuk belajar, terlibat aktif di dalam pelajaran maupun memberikan perhatian saat proses pembelajaran dengan tetap berkonsentrasi. Hasil observasi menunjukkan minat belajar firman Tuhan pada anak usia 6-8 tahun untuk belajar nilai-nilai Alkitab, dan dapat bertumbuh di dalam Tuhan melalui media film.
\end{abstract}

Kata-kata kunci: metode, pembelajaran, film, Superbook, minat, usia

\begin{abstract}
The purpose of this paper is to study the learning method through Superbook film and learning interest God's word in child aged 6-8 years. The method used is descriptive qualitative research method using library research, and field research in the form of observation and interviews with child aged 6-8 years. Criteria for children who are interested if the child is happy to learn, interested in learning, actively involved in the lesson, and giving attention during the learning process by staying focused. The observations show interest in learning God's Word to child aged 6-8 years to learn biblical values, and can grow in God through film media.
\end{abstract}

Keywords: method, learning, film, superbook, interest, age 


\section{Pendahuluan}

Perkembangan teknologi pendidikan masa kini tidak dapat terlepas dari perkembangan teknologi pada umumnya. Berbagai perangkat pendidikan dan sarana pendidikan yang modern turut mendukung peningkatan proses pembelajaran, baik yang ada ditingkat sekolah maupun dalam kehidupan sehari-hari. Pada hakikatnya, pembelajaran adalah sebuah proses komunikasi yang bertujuan untuk menyampaikan informasi sehingga dapat merangsang pikiran, perasaan dan minat serta perhatian peserta didik. Di dalam proses pembelajaran ini, dalam menyampaikan materi atau bahan ajar dapat memakai media. ${ }^{1}$ Media itu sendiri digunakan untuk memperlancar komunikasi dalam proses pembelajaran yang sering disebut dengan media pembelajaran.

Anak-anak di sekolah tumbuh dengan perangkat lunak multimedia, VCR, Internet, dan berbagai gadget elektronik-game, dan mainan yag mereka sukai. Mahasiswa sekarang dapat mengatur panggilan konferensi untuk mendiskusikan materi pelajaran dengan rekan-rekan di lokasi lain dan mengajukan pertanyaan pada saat yang sama. Apa implikasi perkembangan baru ini terhadap pembelajaran dan pengajaran? Apa peran sekolah dan guru untuk memfasilitasi cara baru dalam membangun pengetahuan dan menyebarluaskan informasi ini? Bagaimana kehidupan manusia dipengaruhi oleh teknologi multimedia? ${ }^{2}$

Berbagai perangkat pendidikan, dan sarana pendidikan yang modern juga turut mengambil peran dalam pendidikan Kristen di gerejagereja sekarang ini tidak terkecuali di sekolah minggu. Sekolah minggu memiliki peran penting untuk membawa anak-anak kepada Kristus, di mana di tempat ini kerohanian anak dapat bertumbuh. Allah rindu anak dalam setiap generasi mengerti betapa berharganya mereka di hadapan Allah dan perlunya anak-anak memiliki hubungan dengan Allah melalui Yesus Kristus. $^{3}$

Sekolah minggu yang bagus adalah sekolah minggu yang berpusat pada anak (Child-centered). Pembinaan anak dimulai dari pemahaman yang mendalam tentang siapa anak yang diajar, dan apa kebutuhan dari anak tersebut sehingga dalam menceritakan firman Tuhan bisa memakai

${ }^{1}$ Sapto Haryoko, "Efektivitas Pemanfaatan Media Audio-Visual Sebagai Alternatif Optimalisasi Model Pembelajaran,” Jurnal Edukasi @Elektro 5, no. 1 (Maret 2009):1-2.

${ }^{2}$ Ladislaus Semali, Literacy in Multimedia America: Integrating Media Education across the Curriculum (London: Routledge, imprint of Taylor \& Francis Group, 2018), accessed March 12, 2019,

http://search.ebscohost.com/login.aspx?direct=true\& scope=site\&edb=nlebk\& $\& \mathrm{db}=\mathrm{nlabk}$ $\& A N=1640912$.

${ }^{3}$ Dan Brewster, Child, Church, and Mission (Jakarta: Compassion Internasional, 2011), 181 . 
model pembelajaran yang tepat untuk sekelompok anak di sebuah kelas tertentu. ${ }^{4}$ Salah satu keinginan anak adalah hal-hal yang berkaitan dengan suasana kelas, yaitu mendengar cerita yang menarik dan membangun serta mendapat pengajaran rohani yang sehat. ${ }^{5}$

Sekolah minggu bukan hanya sekadar acara anak, melainkan juga upaya menyelamatkan mereka dari maut yang berarti guru sekolah minggu memiliki peran penting untuk membawa anak-anak kepada Tuhan. Setiap guru dipanggil pada misi penyelamatan anak. Dengan meyakini akan hal ini maka seharusnya guru akan semakin bertambah semangat dalam melayani Tuhan yaitu mengajar sekolah minggu. ${ }^{6}$

Dengan zaman yang serba canggih, tentu guru diwajibkan untuk bisa merancang suatu pembelajaran dengan berbagai model, metode serta media yang dapat membuat pembelajaran di kelas lebih bermakna dan menyenangkan. ${ }^{7}$ Guru sekolah minggu dapat melihat peluang yang ada untuk menyampaikan firman Tuhan secara kreatif. Telah banyak metode pembelajaran yang menggunakan berbagai media yang mengikuti perkembangan zaman salah satunya melalui media audiovisual yang di dalam media ini, dan yang sering digunakan untuk pembelajaran adalah film. Dunia sekarang sedang mengajarkan anakanak melalui berbagai macam media yang ditawarkan kepada anak-anak salah satunya adalah film. Mereka terkadang rela tidak datang ke sekolah minggu hanya untuk menonton film yang mereka gemari pada saat hari minggu pagi. Televisi swasta nasional di Indonesia seringkali menayangkan acara untuk anak-anak. Mereka berlomba menarik minat penonton semaksimal mungkin agar rating naik dalam setiap acara yang ditayangkannya. ${ }^{8}$ Masyarakat, terlebih khusus anak-anak lebih memilih tayangan film animasi atau lebih sering disebut dengan film kartun. Anak-anak sangat gemar film kartun karena lucu, cerita yang disajikan ringan, dan selain itu anak-anak menyukai gambar yang bergerak yang terdiri dari berbagai macam warna untuk menarik perhatian anak dan sesuai dengan dunia anak serta bahasa yang digunakan dalam film kartun cenderung sangat mudah untuk ditangkap dan dimengerti oleh anak-anak.

${ }^{4}$ Lie Paulus, Mereformasi Sekolah Minggu (Yogyakarta: ANDI, 2006), 4.

${ }^{5}$ Paulus, 13.

${ }^{6}$ Paulus, 58-59.

${ }^{7}$ Rima Trianingsih, "Pengantar Praktik Mendidik Anak Usia Sekolah Dasar," Al Ibtida: Jurnal Pendidikan Guru MI 3, no. 2 (Oktober 2016): 209, http://www.syekhnurjati.ac.id/jurnal/index.php/ibtida/article/view/880/692.

${ }^{8}$ Ana Setyandari, "Inovasi Pemanfaatan Media Film Untuk Peningkatan Kemampuan Listening Dalam Pembelajaran Bahasa Inggris," Jurnal Magistra XXVII, no. 91 (Maret 2015): 45. 
Mengajar sejarah dengan film memberikan gambaran pengajaran yang segar, menarik, dan jelas secara efektif meningkatkan instruksi studi sosial. Menggunakan ilustrasi pengajaran sejarah melalui film, membantu guru untuk menerapkan ide-idenya dalam pelajaran berbasis film di kelas mereka sendiri, dan menawarkan pemahaman yang lebih dalam tentang masalah yang terjadi. ${ }^{9}$

Guru sekolah minggu dapat menggunakan media film ini untuk menarik anak untuk mau datang ke sekolah minggu, mendengarkan firman Tuhan, dan menjadikan firman Tuhan sebagai minat belajar mereka sehingga anak-anak akan berkeinginan secara terus menurus dalam belajar firman Tuhan dan menjadikan itu gaya hidup mereka. Telah banyak film yang sekarang bisa didownload sesuai yang akan diajarkan kepada anak-anak salah satunya adalah film Superbook. Film Superbook merupakan animasi Alkitab yang diproduksi oleh pelayanan CBN, dan diluncurkan di tahun 2012 yang menceritakan dua orang yang berteman akrab, dan robot mereka yang menjelajah lorong waktu, dan bertemu dengan tokoh-tokoh Alkitab. Melalui petualangan mereka inilah Superbook membawa pesan Alkitab bagi generasi anak di era digital yang dikemas secara menarik. ${ }^{10}$

Di awal film Superbook, penyajian cerita diberikan masalah-masalah seputar yang anak alami agar anak mengerti. Seperti di dalam cerita film Superbook yang berjudul "Ujian" di awal film ini menceritakan tentang Chris yang mendapatkan permainan yang dia suka dari orang tuanya. Namun, baru saja mendapatkan permainan tersebut, teman dari kedua orang tuanya menelepon untuk meminta bantuan mendapatkan permainan tersebut sebagai penyemangat salah satu anak yang sedang di rawat di rumah sakit. Mendengar hal itu Chris menjadi merasa tidak bahagia, karena di satu sisi ia sangat menginginkan permainan tersebut, tetapi disisi lain, ia merasa sedih mendengar ada seorang anak yang menginginkan permainan tersebut. Setelah itu, Superbook muncul dan membawa Chris, Joy, dan Gismo untuk melilhat kisah Abraham yang diuji oleh Allah yakni memberikan Ishak sebagai korban bakaran kepada Allah. Pelajaran yang dapat diambil di sini, sebagai anak Tuhan terkadang diperhadapkan dengan situasi yang tidak menyenangkan bagi diri sendiri, yang mengharuskan membuat pilihan terberat di dalam hidup serta mengajarkan anak-anak untuk taat kepada Tuhan. Di sini penulis melihat bahwa film ini bisa menjadi metode di dalam

${ }^{9}$ Alan S. Marcus et al., Teaching History with Film : Strategies for Secondary Social

Studies (Routledge, 2018), accessed March 12, 2019,

https://www.taylorfrancis.com/books/9781351137720.

10 "Film Animasi Superbook," diakses 30 Maret 2018,

https://www.superbookindonesia.com/about/animation.html 
menimbulkan minat anak dalam belajar firman Tuhan, karena menghubungakan tentang masalah kehidupan yang biasa anak rasakan di usia mereka dengan kisah Alkitab. Dengan film ini, anak diajarkan selain penerapan firman Tuhan di dalam kehidupan anak, anak juga sekaligus dapat belajar tentang sejarah Alkitab.

Semua anak-anak tentunya sangat menyukai film terlebih film animasi. Anak-anak khususnya anak-anak usia dini (0-8 tahun) sangat menggemari film animasi karena tokohnya yang menarik, bahasa yang ringan, dan banyak perpaduan warna yang semakin membuat anak-anak suka melihatnya. Anak usia dini adalah anak-anak mengalami proses perkembangan perubahan tingkah laku dari yang belum matang menjadi matang, dari sederhana menajadi kompleks, dan lain sebagainya. Anak usia dini memiliki karakteristik yang berbeda dari karakteristik orang dewasa. Anak sangat aktif, dinamis, antusias dan hampir selalu ingin tahu terhadap apa yang dilihat dan didengarnya. ${ }^{.1}$ Disaat inilah saat yang cocok untuk mengenalkan anak-anak serta membawa mereka kepada Yesus. Anak usia 0-8 tahun dibagi lagi menjadi beberapa bagian sesuai dengan tahap tumbuh kembang anak. Pada usia 6-8 tahun, anak telah mulai memasuki tahap sekolah awal di mana anak akan membangun pikiran mereka sendiri berdasarkan eksprerimen yang ia lakukan. Saat anak menemukan benda atau peristiwa baru, anak berupaya untuk memahaminya berdasarkan yang dipikirkannya. ${ }^{12}$

Di Gereja Bethel Indonesia (GBI) Murid Yesus Makassar, penulis adalah salah satu guru sekolah minggu yang mengajar anak-anak di usia 6-8 tahun. Metode yang penulis pakai dalam mengajar firman Tuhan baik itu metode mengajar melalui bercerita, permainan, bernyanyi, drama, dan pemutaran film animasi agar firman Tuhan dapat dimengerti oleh anak-anak serta mereka dapat bertumbuh di dalam iman kepada Tuhan. Namun, di dalam beberapa metode tersebut, penulis melihat anak-anak lebih tertarik saat guru sekolah minggu mengatakan akan ada pemutaran film, dan mereka sangat berantusias untuk segera menonton film tersebut.

Di dalam pelayanan sekolah minggu, telah dijadwalkan anak sekolah minggu menonton film jika di dalam bulan tersebut ada lima minggu, jadi pemutaran film dilakukan setiap minggu kelima di bulan tersebut. Film yang diberikan seperti hiburan bagi anak tetapi di dalam hiburan tersebut anak juga mendapatkan nilai-nilai kehidupan melalui film yang ditonton. Setelah itu, barulah dihubungkan dengan ayat firman Tuhan yang sesuai dengan yang ingin diajarkan kepada anak sekolah

${ }^{11}$ Ernawulan Syaodih, "Perkembangan Anak Usia Dini (6-8 tahun)," http://file.upi.edu/Direktori/FIP/JUR._PGTK/196510011998022ERNAWULAN_SYAODIH/perk_anak_6-8_th_pdf.

12 Lie Paulus, Mereformasi Sekolah Minggu (Yogyakarta: ANDI, 2006), 11. 
minggu. Melalui tulisan ini, penulis menjelaskan secara kualitatif metode pembelajaran melalui media film Superbook untuk meningkatkan minat belajar firman Tuhan pada anak usia 6-8 tahun.

\section{Kajian Teori}

\section{Metode Pembelajaran}

Metode pembelajaran dapat diartikan sebagai cara yang digunakan guru dalam menjalankan fungsinya sebagai seorang pengajar dan merupakan alat untuk mencapai tujuan pembelajaran. Metode pembelajaran merupakan bagian dari strategi pembelajaran yang di mana strategi pembelajaran dapat diartikan sebagai suatu rencana untuk mencapai tujuan yang terdiri dari metode, teknik, dan prosedur untuk menjamin peserta didik bisa mencapai tujuan akhir kegiatan pembelajaran..$^{13}$ Metode dalam rangkaian sistem pembelajaran memegang peran yang sangat penting. Keberhasilan implementasi strategi pembelajaran sangat bergantung pada cara guru menggunakan pembelajaran, karena suatu strategi pembelajaran mungkin hanya bisa diimplementasikan melalui penggunaan metode pembelajaran. ${ }^{14}$ Tetapi, tidak semua metode pembelajaran cocok digunakan untuk mencapai semua tujuan pembelajaran dan keadaan belajar mengajar berlangsung.

Salah satu komponen yang dipakai dalam pembelajaran adalah komponen metode. Metode mengajar yang digunakan harus disesuaikan dengan tujuan pengajaran, dengan kata lain metode pembelajaran harus mendukung pencapaian tujuan pembelajaran tersebut. Tujuan-tujuan itu dapat berhubungan dengan pengetahuan, sikap, keterampilan, maupun tingkah laku. ${ }^{15}$ Tujuan penggunaan metode pembelajaran adalah untuk meningkatkan kualitas proses belajar mengajar dan untuk meningkatkan hasil belajar peserta didik. Dalam penggunaan metode pembelajaran dapat disesuaikan dengan keadaan, dan kemampuan peserta didik yang di dalam pembelajaran, guru dapat lebih kreatif dan maknanya semakin dapat dipahami anak didik dengan lebih baik. Tujuan lainnya, dapat dikatakan bahwa mengajar tidak terlepas dari tujuan serta cara dalam mempersiapkan bahan pengajaran maupun dalam proses belajar mengajar, yang membuat di dalam kegiatan pembelajaran terjalin komunikasi yang baik antara guru dengan peserta didik.

Pengetahuan peserta didik akan semakin kurang jelas jika hanya disampaikan secara lisan. Artinya, peserta didik hanya mengetahui

${ }^{13}$ Hamzah B. Uno dan Nurdin Mohamad, Belajar dengan Pendekatan PAILKEM (Jakarta: Bumi Aksara, 2017), 6-8.

${ }^{14}$ Wina Sanjaya, Strategi Pembelajaran Berorientasi Standar Proses Pendidikan (Jakarta: Kencana, 2014), 7.

${ }^{15}$ Doris Blattner, Bagaimana Mengajar Anak Madya (Bandung: LLN, 1986), 15. 
tentang kata tanpa memahami, dan mengerti makna yang terkandung dalam kata tersebut. Tanpa memakai media pembelajaran, peserta didik kurang bersemangat untuk menangkap maksud dan mengerti pelajaran yang disampingkan karena peserta didik kurang diajak berpikir dan menghayati suatu pelajaran, padahal untuk memahami sesuatu perlu keterlibatan peserta didik baik fisik maupun psikis. ${ }^{16}$ Peranan media pembelajaran sangat diperlukan dalam suatu kegiatan belajar mengajar, dan guru dapat menggunakan film, gambar untuk memberikan informasi yang lebih baik bagi peserta didik. Media pembelajaran dapat membantu guru untuk membawa suatu objek yang tidak mungkin menjadi mungkin ke dalam kelas, dan membantu guru dalam mengajarkan sesuatu yang abstrak atau sulit dipahami oleh peserta didik, sehingga peserta didik dapat mengerti dan memahami pelajaran yang diberikan oleh guru.

Film merupakan salah satu cara yang bisa dipakai di dalam proses pembelajaran bagi anak-anak. Karena film termasuk di dalam salah satu media pembelajaran yaitu media audio-visual. Di dalam karakteristiknya, film memiliki banyak kesamaan dengan video baik itu di dalam kelebihan maupun kekurangan dari film itu sendiri. Namun, biasanya di dalam pembelajaran, penggunaan media film bukan media yang utama melainkan metode kedua yang dipakai di dalam pelajaran. Artinya, biasanya setelah menonton film akan dijelaskan kembali tentang pelajaran tersebut atau biasa memakai metode tambahan agar peserta didik dapat mencapai tujuan dari pembelajaran tersebut.

\section{Media Film Animasi Superbook}

Media film kartun juga digunakan untuk mengembangkan dialog berbahasa antara guru dan siswa. ${ }^{17}$ Pemanfaatan film animasi dalam proses pembelajaran dapat meningkatkan kualitas proses dan hasil belajar karena film animasi bersifat menarik. Jika di dalam pemutaran film animasi dapat menarik perhatian peserta didik, diharapkan informasi yang ingin diberitahukan kepada peserta didik dapat dimengerti. Karena telinga dan mata lebih banyak terlibat untuk menyerap informasi dari film..$^{18}$ Dalam hal ini, konsep film Superbook ini

${ }^{16}$ Wina Sanjaya, Strategi Pembelajaran Berorientasi Standar Proses Pendidikan (Jakarta: Kencana, 2014), 169.

${ }^{17}$ Sri Galuh Witriningrum, Endang Kurniati, and Joko Sukoyo, "Pengembangan Media Film Kartun Berbahasa Jawa Untuk Pembelajaran Dialog Siswa Kelas X SMA Di Banyumas," Jurnal Penelitian Pendidikan 34, no. 1 (August 29, 2017): 77-84.

${ }^{18}$ Umrotul Hasanah \& Lukman Nulhakim, "Pengembangan Media Pembelajaran Film Animasi sebagai Media Pembelajaran Konsep Fotosintesis," Jurnal Penelitian dan Pembelajaran IPA 1, no. 1 (November 2015): 92-94, http://jurnal.untirta.ac.id/index.php/JPPI/article/view/283/184. 
diambil dari kisah-kisah Alkitab sehingga memberikan pengetahuan kepada anak-anak tentang kehidupan kuno Timur Tengah, tempat terjadinya berbagai kisah-kisah di Alkitab yang sesuai dengan umur mereka. Mark McClendon selaku Presiden CBN Indonesia, mengatakan bahwa anak-anak sekarang tinggal di satu generasi yang tidak pernah ada sebelumnya. Artinya anak-anak adalah Google generation, Facebook generation sehingga dalam mereka berpikir, berteman, dan cara berkomunikasi pun berbeda, mereka adalah generasi asli digital. ${ }^{19}$ Artinya, agar tidak kehilangan generasi penerus gereja, Superbook disajikan dengan cara yang disesuaikan dengan kebutuhan anak, yaitu digital yang tentu saja disesuaikan dengan kebutuhan anak dan Superbook memiliki pengetahuan Alkitab yang baik. Dengan adanya film Superbook, banyak anak-anak yang menerima Yesus Kristus sebagai Juruselamat bagi mereka dan merubah sifat yang buruk setelah menonton film Superbook dan dari pertobatan anak-anak, diharapkan anak dapat menceritakan kepada teman-teman sebaya mereka siapa itu Tuhan Yesus di dalam kehidupan mereka. Karena, visi dari Superbook itu sendiri adalah agar generasi anak mengasihi Tuhan, mencintai firman Tuhan, dan menjadi misioner. ${ }^{20}$

Di umur 6-8 tahun, salah satu kemampuan anak adalah memakai sebab akibat dan perkembangannya dalam pemahaman terhadap ruang dan waktu. ${ }^{21}$ Pada usia ini, guru sekolah minggu bisa mengajarkan tentang firman Tuhan kepada anak-anak melalui film karena proses belajar tidak sekadar menghafal konsep-konsep, tetapi bisa memahami tentang kebenaran firman Tuhan melalui audio-visual. Belajar akan lebih bermakna jika anak tersebut mengalami langsung yang dipelajari dengan mengaktifkan lebih banyak indra daripada hanya mendengarkan guru menjelaskan.22 Dengan media film dapat menimbulkan stimulus atau rangsangan bagi anak untuk mengikuti kegiatan belajar sekolah Minggu.

\section{Minat Belajar}

Minat belajar merupakan hal yang penting bagi peserta didik karena merupakan salah satu faktor pendukung dalam keberhasilan peserta didik dalam belajar. Minat secara psikologis dibagi menjadi dua macam, yaitu minat disposional dimana minat berdasarkan pembawaan

19 "Satu Harapan: Superbook, Film Animasi Kisah Alkitab Tayang di Televisi Indonesia," diakses 16 Mei 2018, http://www.satuharapan.com/read-

detail/read/superbook-film-animasi-kisah-alkitab-tayang-di-televisi-indonesia.

${ }^{20}$ Superbook Indonesia, "Bersama Superbook Saat Gereja Mitra Membuka Diri Memberkati Gereja," Youtube, diakses 13 Agustus 2018, http://youtu.be/5PiULXv_ILE

${ }^{21}$ Mohamad Syarif Sumantri, Strategi Pembelajaran Teori dan Praktik di Tingkat

Pendidikan Dasar (Jakarta: RajaGrafindo Persada, 2016), 160.

${ }^{22}$ Sumantri, 162. 
dan menjadi ciri sikap hidup seseorang, dan minat aktual yaitu berlaku pada saat dan minat tersebut merupakan dasar dari proses belajar. ${ }^{23}$ Dalam pengajaran firman Tuhan kepada anak-anak, perlu adanya metode pembelajaran yang dapat menarik minat belajar anak terhadap firman Tuhan. Seperti yang telah dijelaskan bahwa minat belajar itu timbul dari dalam diri anak terhadap sesuatu yang menarik perhatiannya dan berguna bagi dirinya. Salah satu untuk membuat anak berminat dengan pembelajaran yang diberikan adalah dari guru itu sendiri. Guru sekolah minggu harus bisa menarik perhatian anak dengan menggunakan berbagai metode yang dibantu media sebagai pelengkap metode pembelajaran tersebut.

Untuk bisa menarik perhatian anak, guru sekolah minggu terlebih dahulu mengerti bahwa mengajar anak-anak tentang firman Tuhan itu sangat penting. Jika dilihat di dalam Alkitab, banyak firman Tuhan yang memperdulikan anak-anak. Firman Tuhan sendiri pun menyuruh agar orang dewasa dapat mengajarkan anak-anak bahkan secara berulangulang serta mendidik mereka. Di dalam Ulangan 6:4-7, dikatakan bahwa apa yang telah diberitahukan dan diketahui tentang firman Tuhan, haruslah itu diajarkan berulang-ulang kepada anak-anak agar mereka pun tidak lupa akan firman Tuhan. Dengan mengertinya firman Tuhan ini, guru sekolah minggu diharapkan bisa membawa anak-anak agar lebih dekat dengan Tuhan melalui membangkitkan minat belajar anak terhadap firman Tuhan.

Di dalam mengajarkan firman Tuhan kepada anak, penting sekali untuk diketahui yang bisa menjadi daya tarik anak sehingga anak ingin belajar firman Tuhan. Guru sekolah minggu atau gereja harus bisa menjadikan firman Tuhan sebagai salah satu minat mereka untuk belajar atau bahkan minat utama yang ada di dalam diri anak. Untuk bisa menjadikan firman Tuhan sebagai minat belajar anak, guru sekolah bisa memakai berbagai macam metode dan media untuk menarik perhatian anak agar mau mendengarkan yang diajarkan guru.

Metode dengan menggunakan media audio visual merupakan salah satu metode yang biasa dipakai di dalam proses pembelajaran. Metode pembelajaran audio visual tidak dapat dipisahkan dari media audio visual, karena dalam penyajian materi menggunakan alat (media) audio visual. Telah banyak metode dan media yang bisa dipakai untuk sekarang ini, dan salah satu yang sekarang digunakan oleh beberapa gereja di Indonesia adalah film dan banyak film animasi maupun film rohani yang bisa dipakai untuk membangkitkan minat anak untuk belajar firman Tuhan.

${ }^{23}$ Siti Maesaroh, "Peranan Metode Pembelajaran Terhadap Minat dan Prestasi Belajar Pendidikan Agama Islam," Jurnal Kependidikan 1, no. 1 (November 2013): 150-168, http://ejournal.iainpurwokerto.ac.id/index.php/jurnalkependidikan/article/view/536. 
Sejumlah gereja pun sekarang mulai memakai film Superbook untuk dijadikan sebagai salah satu media di dalam pembelajaran agar anak lebih mengerti firman Tuhan. Ada 5.051 gereja yang bergabung di dalam Superbook dan anak kurang lebih 302.968 anak. ${ }^{24}$ Dengan data ini, dapat dilihat bahwa tidak sedikit gereja menyadari bahwa film dapat menjadi salah satu media audio visual yang dapat membantu guru untuk menyampaikan firman Tuhan kepada anak-anak.

Salah satu kelompok usia yang cocok dengan media film di dalam proses pembelajaran adalah kelompok usia 6-8 tahun. Penulis mengatakan ini cocok karena pada usia ini, anak mulai belajar melakukan, membuat, meniru, mendengar, melihat, serta mempertunjukkan, dan menceritakan sesuatu yang mereka lihat dan mereka dengar.

\section{Metode}

Dalam penulisan ini, metode yang digunakan oleh penulis adalah metode kualitatif dengan teknik pengumpulan data sebagai berikut: 25

Pertama, studi kepustakaan yaitu mengadakan penelitian terhadap buku-buku yang berkaitan dengan metode mengajar maupun dari bahan-bahan penulisan lainnya yang berhubungan dengan pembahasan dalam penulisan skripsi.

Kedua, penelitian lapangan yaitu pengambilan data melalui observasi dan wawancara setelah mengajar sekolah minggu memakai metode pembelajaran melalui media film Superbook kepada anak usia 6-8 tahun di GBI Murid Yesus Makassar.

Penulis melaksanakan pengamatan selama kurang lebih selama 3 bulan, mulai dari bulan April sampai bulan Juni yaitu setiap dua minggu sekali ada pemutaran film sebagai media pembelajaran firman Tuhan kepada anak umur 6-8 tahun. Penulis melakukan pemutaran untuk anak umur 6-8 tahun saat penulis bertugas membawakan pelajaran Alkitab kepada anak-anak. Berikut penjelasan yang penulis berikan mengenai waktu dan film yang diputarkan penulis saat penulis mengajar anak sekolah minggu:

Minggu, 14 April 2018

Judul Film: Tipuan si Ular

Penjelasan isi Film: Film Superbook ini menceritakan tentang kejatuhan manusia pertama ke dalam dosa. Chris, Joy, dan robot mereka Gismo di

\footnotetext{
24 "Apa itu Superbook?" diakses 16 Mei 2018, http://www.superbookindonesia.com/about/about_superbook.html.

${ }^{25}$ Hengki Wijaya, Analisis Data Kualitatif Ilmu Pendidikan Teologi (Makassar: Sekolah Tinggi Theologia Jaffray, 2018), 35, 44.
} 
ajak oleh Superbook untuk melihat Lucifer dan pengikut-pengikutnya berperang melawan Mikael serta malaikat lainnya karena Lucifer ingin menguasai surga. Namun, Lucifer berhasil dikalahkan oleh malaikat Mikael dan ia pun di usir dari surga. Setelah melihat Lucifer diusir dari surga, barulah Chris, Joy, dan Gismo di bawa ke taman Eden untuk melihat Adam dan Hawa memberi nama segala jenis hewan dan tumbuhan sampai Adam dan Hawa diusir oleh Allah dari taman akibat ketidaktaatan mereka kepada Allah.

Minggu, 28 April 2018

Film: Ujian

Penjelasan isi Film: Superbook membawa Chris, Joy, dan robot mereka Gismo untuk melihat kisah Alkitab tentang Abraham yang tidak memiliki anak. Tetapi, saat Allah telah memberikan anak kepada Abraham, Allah menguji iman Abraham dengan Allah meminta Abraham untuk memberikan yang paling berharga dihidupnya, yaitu anaknya sendiri, Ishak.

Minggu, 12 Mei 2018

Judul Film: Bebaskan Umatku

Penjelasan Isi Film: Film Superbook ini menceritakan tentang Musa yang dipanggil oleh Allah untuk membawa bangsa Israel keluar dari tanah Mesir. Walaupun banyak rintangan tapi, Tuhan selalu menyertai bangsa Israel. Film ini menceritakan saat Musa berada di Median, Musa diutus oleh Allah, tulah-tulah yang Tuhan berikan kepada bangsa Mesir, sampai akhirnya kepada bangsa Israel yang berhasil menyebrangi laut Teberau.

Untuk mengetahui minat belajar firman Tuhan pada anak usia 6-8 tahun, guru menggunakan minat belajar, yaitu: rasa senang, keterlibatan secara aktif anak, ketertarikan anak data belajar, dan perhatian anak yang merupakan konsentrasi anak saat belajar.

\section{Hasil dan Pembahasan}

Berdasarkan hasil penelitian serta hasil observasi yang diperoleh sebagai berikut:

Pemutaran Film Pertama

Berdasarkan minat belajar karena senang, keenam anak yang penulis amati, merespons dengan sangat senang pada saat penulis (sebagai guru sekolah minggu) membuat kalimat pembuka dalam memulai kelas sekolah minggu. Penulis mengatakan, "Adik-adik hari ini kita akan menonton film." Respons yang mereka tunjukkan adalah ada yang bersorak, ada yang melompat-lompat, dan ada juga yang tertawa dengan gembira. Salah seorang anak bernama Keysia Steally (8 tahun) mengatakan dengan wajah gembira, "Hore, kakak hari ini kita menonton film lagi ya kak?" Minat belajar yang ditunjukkan dengan keterlibatan 
secara aktif saat pemutaran film pertama berlangsung, tiga dari enam orang anak aktif untuk bertanya selama film diputarkan dan mampu menjawab pertanyaan yang diajukan oleh penulis saat film telah selesai diputar. Salah seorang anak bernama Camelia (7 tahun) aktif bertanya saat pemutaran film berlangsung. "Kakak, siapa nama malaikat jahat itu?" dan "Kakak, buah apelkah yang dimakan Adam dengan Hawa itu? Tapi kenapa buah apelnya begitu?" tanya Camelia.

Selesai pemutaran film, penulis bertanya kepada anak-anak: "Sebutkan empat sungai yang ada di taman Eden!" Salah seorang anak bernama Yolan (8 tahun) dapat menjawab ketika penulis bertanya, dan dia menjawab: "Pison, Efrat, Gihon, dan Tigris." ${ }^{26}$ Setelah pemutaran film berlangsung, penulis mewawancarai anak-anak untuk melihat minat anak yang dapat dilihat dari ketertarikan anak dalam menonton film. Lima dari enam anak tertarik saat menonton film. Seorang anak yang kurang tertarik mengatakan: "Saya tidak suka filmnya karena tidak ada lucu-lucunya." 27 Anak yang suka Keiko (6 tahun) mengatakan: "Suka filmnya karena ada robotnya sama ada malaikat-malaikatnya berkelahi." ${ }^{28}$

\section{Pemutaran Film Kedua}

Berdasarkan perasan senang saat belajar firman Tuhan memakai media film Superbook, keenam anak yang penulis amati merespons sangat senang dan gembira. Salah seorang anak bernama Keysia mengatakan, "Kakak Vivit, kakak yang bawa cerita toh? hari ini kita nonton film Superbook atau tidak?" dan penulis menjawab: "Iya, hari ini kita nonton film Superbook." Selesai penulis mengatakan itu, keenam anak tersebut merespons dengan loncat-loncat dan meneriakkan: "Yeay, hore."

Berdasarkan minat belajar keterlibatan secara aktif saat pemutaran film berlangsung, ada lima dari enam orang anak dapat menjawab pertanyaan dari penulis. Penulis bertanya kepada anal-anak: "Siapa yang bisa menceritakan kembali film yang baru ditonton?" Seorang anak bernama Yolan (8 tahun) dapat menjawab:

Saya bisa kak. Abraham punya anak namanya Ishak. Ishak suka memelihara domba karena banyak domba-dombanya tadi. Terus, pas pagipagi, Abraham bawa Ishak pergi ke bukit untuk memberikan korban bakaran. Sampai di bukit, ternyata bukan domba yang dia korbankan tapi Ishak. Setelah Ishak diikat, Tuhan bicara sama Abraham untuk tidak bakar Ishak dan Ishak dilepaskan diganti dengan domba. ${ }^{29}$

\footnotetext{
${ }^{26}$ Yolan, Wawancara Oleh Penulis, Makassar, 14 April 2018

${ }^{27}$ Kevin, Wawancara Oleh Penulis, Makassar, 14 April 2018.

${ }^{28}$ Keiko, Wawancara Oleh Penulis, Makassar, 14 April 2018.

${ }^{29}$ Yolan, Wawancara Oleh Penulis, Makassar, 14 April 2018.
} 
Berdasarkan minat belajar yaitu anak berantusias saat menonton film, penulis mengamati empat dari lima anak tertarik saat menonton film karena mereka semakin berantusias saat Ishak mau dikorbankan oleh Abraham menjadi korban bakaran bagi Allah. Keiko (6 tahun) bertanya: "Ih, beneran mau dibakarkah anaknya?" Adeline (8 tahun) mengatakan: "Kasihannya mau dibakar," Keysia (8 tahun) mengatakan: "Kakak Vivit, tidak jadi dibakar toh itu kakak." Camelia (7 tahun) mengatakan: "kasihannya Ishak."

Berdasarkan pengamatan penulis, lima dari enam anak memperhatikan film tersebut hingga selesai dengan tetap fokus walaupun sempat ribut karena bertanya-tanya tentang Ishak akan dibakar oleh Abraham atau tidak. Satu anak, penulis amati kurang memberikan perhatian penuh, hal ini ditunjukkan anak tersebut gelisah dan tidak bisa tenang ditempat duduknya.

\section{Pemutaran Film Ketiga}

Berdasarkan perasaan senang saat belajar firman Tuhan memakai media film Superbook, ada lima anak yang penulis amati dan kelimanya merasa senang. Saat pembukaan sekolah minggu, salah seorang teman penulis yang sebagai guru sekolah minggu mengatakan: "Ya anak-anak hari ini kita akan menonton film yang akan dibawakan oleh kakak Vivit. Semuanya duduk di kursinya masing-masing." Setelah mendengar itu, anak-anak dengan bersamaan mengatakan: "Superbook!" Maka dapat dianalisis bahwa saat penulis memakai film sebagai media belajar firman Tuhan, anak-anak tetap menyambut dengan sangat senang film Superbook ini.

Setelah pemutaran film, penulis bertanya kepada anak-anak dan memberikan kesempatan untuk setiap anak menjawabnya. Penulis bertanya: "Sebutkan tulah-tulah yang kalian ingat dari film tadi!"

Adeline (8 tahun) menjawab: "Air menjadi darah, katak, nyamuk, lalat, penyakit sampar pada ternak, bisul, hujan es, belalang, gelap, dan anak sulung mati." ${ }^{30}$ Keysia ( 8 tahun) menjawab: "Air menjadi darah, hujan es, belalang, lalat, nyamuk, penyakit sampar, kodok, gelap gulita, anak sulung mati." ${ }^{31}$ Camelia (7 tahun) menjawab: "Kakak tidak ku ingat semua. Saya cuman ingat air menjadi darah, hujan es batu, nyamuk, lalat, anak sulung mati, gelap gulita, kodok, sama belalang." ${ }^{2}$ Yolan (8 tahun) menjawab: "Hujan es, nyamuk, lalat, air menjadi darah." ${ }^{33}$ Keiko (6

\footnotetext{
30 Adelin, Wawancara Oleh Penulis, Makassar, 12 Mei 2018.

${ }^{31}$ Keysia, Wawancara Oleh Penulis, Makassar, 12 Mei 2018.

${ }^{32}$ Camelia, Wawancara Oleh Penulis, Makassar, 12 Mei 2018.

${ }^{33}$ Yolan, Wawancara Oleh Penulis, Makassar, 12 Mei 2018.
} 
tahun) menjawab: "Kakak, saya tidak hafal. Saya Cuma ingat anaknya mati, hujan es batu, belalang." 34

Penulis mengamati walaupun tidak semua anak dapat menghafal kesepuluh tulah melalui film Superbook, tetapi dapat diketahui dengan film ini menunjukkan anak berminat untuk belajar firman Tuhan, dan dapat menjawab pertanyaan yang diberikan oleh penulis (sebagai guru sekolah minggu).

\section{Film Superbook dan Minat Belajar}

Berdasarkan hasil pengamatan dan wawancara merangkumnya sebagai berikut.

Pertama, media film Superbook dapat membuat anak memiliki minat belajar firman Tuhan yaitu sangat senang saat menonton film Superbook. Kedua, melalui media film Superbook sebagian besar anak cukup aktif dalam pembelajaran firman Tuhan walau ada beberapa yang tidak aktif. Ketiga, dengan memakai film Superbook anak-anak cukup tertarik belajar firman Tuhan. Keempat, dengan memakai film Superbook anak-anak memberi perhatian mereka, dan fokus saat pemutaran film.

Dengan film Superbook ini, anak dapat belajar dengan baik karena durasi film tidak terlalu panjang yakni 20-25 menit sehingga anak tidak menjadi bosan. Dalam perkembangan emosi, anak ingin tahu dalam segala hal, baik yang ada di dalam rumah maupun lingkungan di luar rumah mereka dan daya konsentrasi anak meningkat serta berpikir dan berimajinasi dengan baik. Dengan keingintahuan ini dapat membangkitkan minat belajar anak, karena film Superbook itu sendiri pun, setiap episode temanya berganti-ganti serta melalui film ini, anak diajak untuk berimajinasi dan berpikir dengan baik.

Dari segi perkembangan moral, menurut penulis media Superbook cocok untuk anak usia 6-8 tahun karena film Superbook bukan hanya membuat anak untuk berimajinasi saja, melainkan dapat mendidik anak untuk memiliki perilaku yang baik. Artinya, bukan hanya mengembangkan imajinasi anak dengan apa yang ditontonnya, tetapi juga melalui film Superbook ini diharapkan anak untuk bisa mendapatkan pelajaran moral setelah menonton film Superbook.

Dari segi perkembangan spiritual, media Superbook menurut penulis cocok untuk anak usia 6-8 tahun, karena melalui film Superbook membuat anak lebih mengingat tokoh-tokoh Alkitab yang diceritakan di dalam film tersebut. Sehingga, anak dapat menyukai cerita Alkitab dan dapat menerima kasih yang mengampuni dalam pengalaman di dalam kelas sekolah minggunya.

${ }^{34}$ Keiko, Wawancara Oleh Penulis, Makassar, 12 Mei 2018. 


\section{Kesimpulan}

Film Superbook merupakan salah satu media pembelajaran yang dibuat supayabisa menjawab kebutuhan anak zaman sekarang melalui kegemaran anak yakni film animasi. Minat belajar sangat penting untuk menentukan hasil akhir dari proses pembelajaran. Melalui media film dapat terlihat minat anak dengan ciri-ciri anak senang untuk belajar, tertarik untuk belajar, terlibat aktif di dalam pelajaran maupun memberikan perhatian saat proses pembelajaran dengan tetap berkonsentrasi dan fokus.

\section{Kepustakaan}

“Apa itu Superbook?” Diakses 16 Mei 2018. http://www.superbookindonesia.com/about/about_superbook.htm 1 .

Brewster, Dan. Child, Church, and Mission. Jakarta: Compassion Internasional, 2011.

Djamarah, Syaiful Bahri \& Aswan Zain, Strategi Belajar Mengajar.Jakarta: Rineka Cipta, 1997.

"Film Animasi Superbook." Diakses 30 Maret 2018. https://www.superbookindonesia.com/about/animation.html

Haryoko, Sapto. "Efektivitas Pemanfaatan Media Audio-Visual Sebagai Alternatif Optimalisasi Model Pembelajaran." Jurnal Edukasi @Elektro 5, no. 1 (Maret 2009):1-10.

Hasanah, Umrotul \& Lukman Nulhakim, "Pengembangan Media Pembelajaran Film Animasi sebagai Media Pembelajaran Konsep Fotosintesis," Jurnal Penelitian dan Pembelajaran IPA 1, no. 1 (November 2015): 91-106.

Maesaroh, Siti. "Peranan Metode Pembelajaran Terhadap Minat dan Prestasi Belajar Pendidikan Agama Islam." Jurnal Kependidikan 1, no. 1 (November 2013): 150-168.

Marcus, Alan S., Scott Alan Metzger, Richard J. Paxton, Jeremy D. Stoddard, Scott Alan Metzger, Richard J. Paxton, and Jeremy D. Stoddard. Teaching History with Film: Strategies for Secondary Social Studies. Routledge, 2018. Accessed March 12, 2019. https://www.taylorfrancis.com/books/9781351137720.

Paulus, Lie. Mereformasi Sekolah Minggu. Yogyakarta: ANDI, 2006.

Sanjaya, Wina. Strategi Pembelajaran Berorientasi Standar Proses Pendidikan. Jakarta: Kencana, 2014.

"Satu Harapan: Superbook, Film Animasi Kisah Alkitab Tayang di Televisi Indonesia." Diakses 16 Mei 2018. 
http://www.satuharapan.com/read-detail/read/superbook-filmanimasi-kisah-alkitab-tayang-di-televisi-indonesia.

Semali, Ladislaus. Literacy in Multimedia America: Integrating Media Education across the Curriculum. London: Routledge, imprint of Taylor \& Francis Group, 2018. Accessed March 12, 2019.

http://search.ebscohost.com/login.aspx?direct=true\&sscope=site\&d $\mathrm{b}=$ nlebk\& $\& \mathrm{db}=$ nlabk\& $\& \mathrm{AN}=1640912$.

Setyandari, Ana. "Inovasi Pemanfaatan Media Film Untuk Peningkatan Kemampuan Listening Dalam Pembelajaran Bahasa Inggris." Jurnal Magistra XXVII, no. 91 (Maret 2015): 45-52.

Sumantri, Mohamad Syarif. Strategi Pembelajaran Teori dan Praktik di Tingkat Pendidikan Dasar. Jakarta: RajaGrafindo Persada, 2016.

Superbook Indonesia. "Bersama Superbook Saat Gereja Mitra Membuka Diri Memberkati Gereja." Youtube, diakses 13 Agustus 2018, http://youtu.be/5PiULXv_ILE

Syaodih, Ernawulan. "Perkembangan Anak Usia Dini (6-8 tahun)." http:/file.upi.edu/Direktori/FIP/JUR._PGTK/196510011998022ERNAWULAN_SYAODIH/perk_anak_6-8_th_pdf.

Trianingsih, Rima. "Pengantar Praktik Mendidik Anak Usia Sekolah Dasar." Al Ibtida: Jurnal Pendidikan Guru MI 3, no. 2 (Oktober 2016): 197-211.

Uno, Hamzah B. dan Nurdin Mohamad. Belajar dengan Pendekatan PAILKEM. Jakarta: Bumi Aksara, 2017.

Wijaya, Hengki. Analisis Data Kualitatif Ilmu Pendidikan Teologi. Makassar: Sekolah Tinggi Theologia Jaffray, 2018.

Witriningrum, Sri Galuh, Endang Kurniati, and Joko Sukoyo. "Pengembangan Media Film Kartun Berbahasa Jawa Untuk Pembelajaran Dialog Siswa Kelas X SMA Di Banyumas." Jurnal Penelitian Pendidikan 34, no. 1 (August 29, 2017): 77-84. 